\title{
Analysis of the composition of milk in the first three lactations in Ayrshire cattle across four decades
}

https://doi.org/10.1515/opag-2018-0026

received February 12, 2018; accepted June 29, 2018

\begin{abstract}
Using historic lactation records for Ayrshire cattle, we report a gradual increase in the production of milk, butter fat and protein levels across four decades. This was generally at the extent of attaining a level of increase per decade which was similar to the increase seen between animals during their first and second lactations in the previous decade. However these increases were achieved without significantly affecting the percentage of butter fat or protein throughout the time examined, and also without changing the heifer: second lactation ratios.
\end{abstract}

Keywords: Ayrshire cattle; milk yields; butter composition; protein composition; temporal variation

\section{Background}

Although internationally, much of modern milk production is dominated by the Holstein breed of cattle, there are still several other breeds around the world which are maintained as dairy cows. In many cases these breeds bear the name of their area of origin (e.g. Jersey, Guernsey, Ayrshire, Friesian). The relative abundance of these other breeds has declined over the last 60-70 years as the Holstein has become the predominant dairy breed (Capper et al. 2009), although each of these breeds still has an organisation (breed society) which was founded to promote the breed, as well as to maintain pedigree and production records associated with animals within the breed.

\footnotetext{
*Corresponding author: Neil R. McEwan, School of Pharmacy and Life Sciences, Robert Gordon University, Aberdeen, AB10 7GJ, Scotland, E-mail: n.mcewan@rgu.ac.uk

Roxanne B. Knight, Neil R. McEwan, Institute of Biological, Environmental and Rural Sciences, Aberystwyth University, Aberystwyth, SY23 3DA, Wales
}

Records held by these societies have been used to assist dairy farmers with decision making in the context of selecting factors such as which animals to retain as replacement stock within a herd, as well as which animals to consider buying at auction from other breeders as means of trying to enhance their own herd. Therefore it is important to maintain accurate records of a number of the traits which are considered desirable. Such records have routinely included: total milk production; the time taken to produce this quantity of milk; and fat content of the milk. In addition, depending on the year(s) during which records were made, some records contain details of milk protein quantities, somatic cell counts within the milk, or classification score based on the conformation of the animal.

These data also allow scientists to study records to look at the relationship between different factors and variables. These records can involve comparisons at different stages within a single lactation for individual animals (e.g. Pontecorvo 1940), between lactations for individual animals (e.g. Archer et al. 2014), between related animals within the breed or herd (e.g. Tabler et al. 1950), or comparisons between animals from different breeds (e.g. White et al. 2001). Generally reports using individual lactation records have been restricted to a relatively short time scale (e.g. no more than 2 or 3 years).

Application of the information from these data also allows an insight into potential correlation between different variables. For example, early work on one of the dairy breeds, the Ayrshire, suggested that there may be a large negative correlation between classification rating (based on conformation of the animal) and milk fat production (Freeman and Dunbar 1955), although this was not found in subsequent work by members of the same group (Butcher et al. 1963) when they reported that milk fat had a reasonable heritability value. These data continue to prove useful as more recently, combining information from milk records with molecular genetic approaches has allowed some degree of localisation of 
genes involved in traits such as fat and protein content to specific chromosomal loci (e.g. Velmala et al. 1999).

To our knowledge there has not been an investigation which has carried out a study of comparative data of milk yields, butter fat quantities and percentages and protein quantities and percentages, from different time points over an extensive time period. The current work makes use of data from the Ayrshire Cattle Society, to investigate the relationship between milk measurements across four decades.

\section{Materials and Methods}

All data were obtained from records held by the Ayrshire Cattle Society which were available from (http://www. ayrshirescs.org/animal_search). One hundred heifers calving for the first time in each of four decades (1960s, 1970s, 1980s and 1990s) were selected. Records used were restricted to animals where all of the first three lactations lasted $305(+10)$ days and where the difference between duration of lactations was no more than 10 days for any single animal. In addition all records had to start in the same decade and any animal known to be descended from red Holsteins (i.e. not pure Ayrshires) were excluded. Due to the number of red Holstein sires used after the 1990s the number of pure Ayrshires diminished and for this reason more recent records were not included. The catalogues of animals presented for sale at the Annual Show and Sale of pedigree animals at the County Auction Mart, Ayr in November 1963, November 1969, March 1975, March 1977, November 1984, November 1986 and November 1998 were used to identify the farms most frequently selling livestock and these farms were used as the key prefix names for animal searches, starting with the most abundant name in these catalogues. In each case, a maximum of four animals per decade were included for each farm, and only one animal per matriarchal lineage (based on animals from a matriarchal line sharing the same name) per farm was used.

For all animals the following data were recorded: name; year of first calving; duration of first, second and third lactation in days; milk yield for each of these lactations; fat content for each lactation; protein content (1980s and 1990s only - data were not routinely available for 1960s and only part of the 1970s as part of the milk recording process) for each lactation. From these values percentage fat and percentage protein were both calculated.

Data were checked by kurtosis and skewness to determine if values were normally distributed. Where values lay at more than twice the standard error, these were assumed to be non-normally distributed. In all cases the data were found to be non-normally distributed, and so were analysed using Spearman's rank correlation test (Spearman 1904), which is suitable for non-parametric data. Data were ranked within each dataset and then comparisons between samples across pairs of datasets were carried out by calculating the correlation coefficient $\left(r_{s}\right)$ using equation 1 . This was then converted (equation 2) into a form which could be compared against t-test values (Kendall and Stuart 1973)

$$
r_{s}=1-\frac{6 \sum d^{2}}{\left(n^{3}-n\right)}
$$

Equation 1

Where $d$ is the difference in respective ranking values between equivalent samples from the two populations and $n$ is the number of samples in each population.

$$
t=r_{s} \sqrt{\frac{n-2}{1-r_{s}^{2}}}
$$

Equation 2

Generic comparisons between values from different decades were performed using Kruskal Wallis analysis and individual pair-wise comparisons between generations were performed using a Nemenyi's test.

Ethical approval: The conducted research is not related to either human or animals use.

\section{Results}

The results of the analyses are shown in Table 1. In all four decades studied, the mean yield of a heifer during her first lactation was approximately the $90 \%$ of the yield achieved during the second lactation, which in turn was around $95 \%$ of the milk yield achieved as a third lactation cow. In addition, there is a general trend of milk levels in animals to increase over time. There is a general pattern whereby animals take one less lactation to reach a certain level of production relative to those from a decade previously (e.g. first lactation levels in the 1970s are similar to those seen in second lactations in cows in the 1960s). The heifer : cow ratio (based on the cow's second lactation) was consistently around 0.9.

There is a similar pattern seen with the quantity of milk fat produced, whereby there is an increase in the total fat production relative to lactation, and there is also a general increase in the fat production by any given animal relative to an equivalent animal in the previous decade. Again this approximates to animals taking one lactation less to produce an equivalent quantity relative to animals from the previous decade. 
Table 1: Values shown are for the means for the first three lactations for each of the four decades examined and include total milk production (kg) as well as percentage protein (only available for 1980 s and 1990s) and percentage fat as well the mean proportion of milk production by each heifer during her first lactation relative to her second lactation. Values shown in parenthesis are standard error of the mean (SEM) values. Samples within any row which are not significantly different (i.e. P>0.05) share the same superscript. N/A denotes values were not available

\begin{tabular}{|c|c|c|c|c|c|c|c|c|c|c|c|c|}
\hline & \multicolumn{3}{|c|}{$1960 s$} & \multicolumn{3}{|c|}{1970 s } & \multicolumn{3}{|c|}{$1980 \mathrm{~s}$} & \multicolumn{3}{|c|}{$1990 \mathrm{~s}$} \\
\hline & Lac 1 & Lac 2 & Lac 3 & Lac 1 & Lac 2 & Lac 3 & Lac 1 & Lac 2 & Lac 3 & Lac 1 & Lac 2 & Lac 3 \\
\hline \multirow[t]{2}{*}{ Mean milk produced (kg) } & $4785^{a}$ & $5243^{b c}$ & 5510 de & $5034^{\mathrm{b}}$ & 5523 df & $5889 \mathrm{gh}$ & $5385^{\text {cef }}$ & $5984 \mathrm{gi}$ & $6258^{i}$ & $5962^{\text {hi }}$ & $6617^{i}$ & $7036^{k}$ \\
\hline & $(71.4)$ & $(90.1)$ & $(96.8)$ & $(91.4)$ & $(101.4)$ & $(107.0)$ & (99.3) & (123.3) & $(119.8)$ & $(98.0)$ & $(127.6)$ & (135.9) \\
\hline Heifer $: 2^{\text {nd }}$ lactation ratio & & 0.91 & & & 0.91 & & & 0.90 & & & 0.90 & \\
\hline \multirow[t]{2}{*}{ Mean fat produced (kg) } & $194^{a}$ & $211^{b c}$ & $224^{d}$ & $205^{b}$ & $225^{\mathrm{de}}$ & $236^{f}$ & $215^{\mathrm{ce}}$ & $235^{d f}$ & $246^{f}$ & $240^{f}$ & $262^{g}$ & $276^{\mathrm{h}}$ \\
\hline & (3.2) & $(4.0)$ & (4.3) & (3.9) & $(4.6)$ & $(4.4)$ & $(4.1)$ & $(5.1)$ & (5.3) & (3.7) & $(4.8)$ & $(5.2)$ \\
\hline \multirow[t]{2}{*}{ Mean fat percentage } & $4.06^{a}$ & $4.02^{\mathrm{ab}}$ & $4.07^{\mathrm{a}}$ & $4.08^{a}$ & $4.08^{a}$ & $4.02^{\mathrm{ab}}$ & $4.00^{\mathrm{ab}}$ & $3.94 \mathrm{bcd}$ & $3.94^{b c}$ & $4.05^{\mathrm{ad}}$ & $3.99^{\text {acd }}$ & $3.95^{\mathrm{bcd}}$ \\
\hline & $(0.03)$ & $(0.03)$ & $(0.04)$ & $(0.03)$ & $(0.04)$ & $(0.03)$ & $(0.04)$ & $(0.04)$ & $(0.05)$ & $(0.04)$ & $(0.04)$ & $(0.04)$ \\
\hline \multirow[t]{2}{*}{ Mean protein produced $(\mathrm{kg})$} & $\mathrm{N} / \mathrm{A}$ & $\mathrm{N} / \mathrm{A}$ & $\mathrm{N} / \mathrm{A}$ & $\mathrm{N} / \mathrm{A}$ & $\mathrm{N} / \mathrm{A}$ & $\mathrm{N} / \mathrm{A}$ & $182^{\mathrm{a}}$ & $211^{\mathrm{b}}$ & $208^{\mathrm{b}}$ & $202^{\mathrm{b}}$ & $225^{c}$ & $237^{d}$ \\
\hline & - & - & - & - & - & - & (3.3) & $(11.0)$ & $(4.0)$ & $(3.3)$ & $(4.1)$ & $(4.3)$ \\
\hline \multirow[t]{2}{*}{ Mean protein percentage } & $\mathrm{N} / \mathrm{A}$ & $\mathrm{N} / \mathrm{A}$ & $\mathrm{N} / \mathrm{A}$ & $\mathrm{N} / \mathrm{A}$ & $\mathrm{N} / \mathrm{A}$ & $\mathrm{N} / \mathrm{A}$ & $3.39^{\mathrm{ab}}$ & $3.67^{\mathrm{ac}}$ & $3.33^{c}$ & $3.40^{\mathrm{ab}}$ & $3.42^{\mathrm{b}}$ & $3.38^{a b}$ \\
\hline & - & - & - & - & - & - & $(0.023)$ & $(0.328)$ & $(0.022)$ & $(0.024)$ & $(0.028)$ & $(0.021)$ \\
\hline
\end{tabular}

Although the absolute quantity of butter fat production increased with lactation and also with decade, the percentage of fat in the milk did not increase. Instead there appears to be a general trend for the percentage of fat to decrease marginally. This is generally true both for lactations from an animal and between decades.

In the case of protein production, only data from the 1980 s and 1990s were available, with records not routinely being kept for the1960s with regular commercial recording of protein data only being introduced part way through the 1970s. Since there are only data for two decades present, this makes comparisons more difficult. However there is again an apparent increase in quantity between decades, with the total quantity of protein produced per animal increasing between the 1980s and 1990s. The percentage of protein during the first lactation did not significantly vary between these two decades, was higher in the second lactation values from the 1980s relative to the 1990s, but lower in the third lactations from the 1980s relative to the values from the 1990s. It is also worth noting that in both decades the highest percentage of protein content is actually during lactation two, rather than lactation three, although this difference was not significant within values from a single decade.

\section{Discussion}

The data presented here are based on cattle records from pure-bred animals across four different decades. Extending this dataset was not realistic. Records prior to the 1960s were often not maintained, or where they were, lactation lengths were often much longer than 305 days, meaning comparisons with the current data would not be possible. More recently (post 2000) many breeders of Ayrshire cattle have used red and white Holstein sires in an effort to increase the size of the animals and the amount of milk they produce, while still maintaining the characteristic red/brown and white colour of animals in the breed, meaning that comparisons between animals from the closed gene pool of earlier years was not possible.

The observation that the yields observed for the more recent decades were higher than those for the earlier decades is not particularly surprising, as typical annual milk yields per animal have increased from around $2000 \mathrm{~kg}$ to $9000 \mathrm{~kg}$ between the $1940 \mathrm{~s}$ and the 2000 s (Capper et al. 2009). This is likely to be due to a number of factors, some due to genetic selection, others due to husbandry and/or nutrition, although the impact of this cannot be determined from the information archived in the database 
used. However it is interesting to note that the values for the heifer : second lactation ratio was either 0.91 or 0.90 in all decades in this study. This is more similar to the value Capper et al. (2009) reported for animals from 1944 (0.89) than the value of 0.83 which they observed for 2007. However, the 2007 figures were dominated by Holstein data, as opposed to the values from 1944 being dominated by smaller breeds, which include Ayrshires, which formed the focus of the current work.

Our observations of milk protein content in the 1980s and 1990s was routinely around $3.3 \%$ to $3.4 \%$, with the exception of lactation 2 in the 1980s, which was higher, although not always statistically so relative to other values. This is more similar to the 1944 values of 3.50\% reported for smaller breeds (including Ayrshires) and $3.20 \%$ for larger breeds than it is for the 2007 value of 3.05\% (Capper et al. 2009). Although the quantity of protein in the milk did increase from the 1980s to the 1990s, this was due to an increase in the total volume of milk, rather than the percentage of protein per se.

Correlations between milk yield and butter fat percentage is a topic which has been considered previously in the Ayrshire breed (Bonnier 1927). Our fat percentage figures of around 4\% lie between the $4.20 \%$ reported by Capper et al. (2009) for small breeds in 1944 and the first three lactations $(3.85 \%, 3.90 \%$ and $3.78 \%$ ) reported for 1908 and 1909 by an earlier investigation (Pearl and Miner, 1919). However they are higher than values reported by Capper et al. (2009) for larger breeds in 1944 (3.60\%) and primarily Holsteins in 2007 (3.69\%). This consistency of value is particularly interesting as the $4.20 \%$ in the earlier work included Jersey cattle in the smaller category, a breed which carries a reputation for high butter fat content, with historic reports of over 5\% (Roberts 1918; Copeland 1927) which can be increased by milking three times daily (Copeland 1934) and current approximations of 5.46\% are listed on the breed society's homepage (http://www. ukjerseys.com/). This consistency of butter fat percentage across the four decades is particularly interesting as this period including a time when many breeders of Ayrshire cattle would include a few Jersey cattle in the herd. This practice was adopted due to the high butter fat content in the milk of Jersey cattle and was an attempt to increase the average butter fat composition across the herd. From these data it is unclear if there was an unsuccessful effort made to increase the average butter fat percentage in the Ayrshires, or if no such effort was made, instead relying on the Jersey cattle within the herd. In either event, no significant change to the butter fat composition was detected across the decades studied.

It is also known that there can be a seasonal effect in terms of milk production, with autumn and winter calving cattle having higher yields, which are offset by lower protein and fat content (Feltes et al. 2016), which corroborates previous observations (Quist et al. 2008). The work of Feltes et al. also described an effect due to the age of the cow at calving in terms of both milk yield (46 to 93 months being highest) and fat (94 to 118 months being highest). In the case of the milk yield this goes beyond the upper study age presented here but does confirm the observation that volume increases after the first lactation. The values for highest fat are all beyond the ages presented here, and cannot be compared. In addition, other factors also merit consideration with the sex of the calf born having an impact on milk yield (heifer calves being advantageous for first calving heifers, and bull calves being advantageous in second lactations). Moreover there is an effect on fat production in the first lactation (bull calves resulting in a higher saturated fat content) but no gender bias in the second lactation.

In conclusion we report from data, where available, across four decades investigated there was a general increase in the quantity of milk produced, the quantity of butter fat produced, and the quantity of protein produced. These are the only four decades which can be analysed in this way as prior to the 1960s many records were not restricted to 305 lactations, and more recently the introduction of Holstein bloodlines into the Ayrshire breed mean that similar comparisons with pure Ayrshires is not possible beyond the 1990s. However in terms of percentage of butter fat and protein, there was not as much temporal change as was the case for the heifer: second lactation ratio for total milk production.

Conflict of interest: Authors state no conflict of interest.

\section{References}

Archer S.C., Mc Coy F., Wapenaar W., Green M.J., Association between somatic cell count during the first lactation and the cumulative milk yield of cows in Irish dairy herds, J. Dairy Sci., 2014, 97, 2135-2144

Bonnier G., Correlations between milk-yield and butter-fatpercentage in Ayrshire cattle - I - Individual correlation, Hereditas, 1927, 10, 230-236

Butcher D.F., Mitchell R.G., Porterfield I.D., Dunbar R.S. Jr., Heritability, Phenotypic and Genetic Correlations between Type Rating and Milk Fat Production in Ayrshire Cattle, J. Dairy Sci., 1963, 46, 971-975

Capper J.L., Cady R.A., Bauman D.E., The environmental impact of dairy production: 1944 compared with 2007, J. Anim. Sci., 2009, 87, 2160-2167 
Copeland L., Inheritance of Butterfat Percentage in Jersey Cows, J. Dairy Sci., 1927, 10, 344-352

Copeland L., Milk and Butterfat Yields of Jersey Cows as Affected by Frequency of Milking, J. Dairy Sci., 1934, 17, 815-821

Feltes G.L., Michelotti V.T., Prestes A.M., Bravo A.P., Bondan C., Dornelles M. de A., Breda F.C., Rorato P.R.N., Milk production and percentages of fat and protein in Holstein breed cows raised in Rio Grande do Sul, Brazil, Cienc. Rural, 2016, 46, 700-706

Freeman A.E., Dunbar R.S. Jr., Genetic Analysis of the Components of Type Conformation and Production in Ayrshire Cows, J. Dairy Sci., 1955, 38, 428-437

Gillespie A.V., Ehlrich J.L., Grove-White D.H., Effect of Calf Gender on Milk Yield and Fatty Acid Content in Holstein Dairy Cows, PLoS ONE, 2017, http://journals.plos.org/plosone/ article?id=10.1371/journal. pone. 0169503

Kendall M.G., Stuart A., The Advanced Theory of Statistics, Volume 2: Inference and Relationship, Griffin Publishers, 1973

Pearl R., Miner J.R., Variation of Ayrshire cows in the quantity and fat content of their milk, J. Agric. Res., 1919, 17, 285-322
Pontecorvo G., A study of persistency in a herd of Ayrshire cows, J. Dairy Res., 1940, 11, 113-120

Quist M.A., LeBlanc S.J., Hand K.J, Lazenby D., Miglior F., Kelton D.F., Milking-to-Milking Variability for Milk Yield, Fat and Protein Percentage, and Somatic Cell Count, J. Dairy Sci., 2008, 91, 3412-3423

Roberts E., Correlation between the Percentages of Fat in Cow's Milk and the Yield, J. Agric. Res., 1918, 14, 67-96

Spearman C., The proof and measurement of association between two things, Am. J. Psychol., 1904, 15, 72-101

Tabler K.A., Tyler W.J., Hyatt G., Differences in milk and butterfat production and test of Ayrshire cow families, J. Dairy Sci., 1950, 33, 449-456

Velmala R.J., Vilkki .H.J., Elo K.T., de Koning D.J., Maki-Tanila A.V., A search for quantitative traits on chromosome 6 in Finnish Ayrshire cattle, Anim. Genet., 1999, 30, 136-143

White S.L., Bertrand J.A., Wade M.R., Washburn S.P., Green J.T., Jenkins T.C., J. Dairy Sci., 2001, 84, 2295-2301 